\title{
COVID-19: INCREASE THE INFESTATION AND DEATH RATE ON JULY - AUGUST 2021 IN BANGLADESH
}

\author{
Ahasan Ullah Khan \\ Department of Entomology, \\ Sylhet Agricultural \\ University, Sylhet-3100, \\ Bangladesh \\ ahasanullahsau@gmail.com
}

\author{
Sarah Tasnim \\ Department of Crop Genetics \\ and Plant Breeding, Institute \\ of Crop Science, Beijing, \\ China \\ sarahtasnim92@gmail.com
}

\author{
Rumana Akter \\ Sir Salimulah Medical College, \\ Mitford, Babubazar Dhaka- \\ 1000 , \\ Bangladesh \\ rumanaruna3@gmail.com
}

Anayat Ullah Khan
Department of Mathematics,
Jashore University of Science
and Technology, Jashore-7408,
Bangladesh
justianmath171521@gmail.com

Foyj Ullah Khan

Department of Information and

Communication Technology,

Mawala Bhashani Science and

Technology, Tangail-1902,

$$
\text { Bangladesh }
$$

md.foyjullahkhan@gmail.com

\author{
Ayesha Shiddika Afsana \\ Department of Poultry Science, \\ Bangladesh Agricultural \\ University, Mymensingh-2202, \\ Bangladesh \\ ayeshashiddika117bau@gmail.com
}

\author{
Shakhera Khanom \\ Department of Information and \\ Communication Technology, \\ Mawala Bhashani Science and \\ Technology, Tangail-1902, \\ Bangladesh \\ shakheraictian33@gmail.com
}

$$
\begin{gathered}
\text { Bidyut Das } \\
\text { Department of Pharmacology, } \\
\text { Faculty of DVM, Sylhet } \\
\text { Agricultural University, Sylhet- } \\
\text { 3100, Bangladesh } \\
\text { dr.bidyut41@ @mail.com }
\end{gathered}
$$

https://doi.org/10.48161/qaj.v2n1a93

Abstract - The novel coronavirus disease is highly infested globally and the first COVID-19 positive patient was on March 8, 2020, in Bangladesh. The objective of this experiment was linked to the relation of tests, infested, recovered, and death of people against the novel coronavirus disease of Bangladesh. The experiment was carried out from July 2021 to August 2021 (N=62 days) to detect COVID-19 in Bangladesh. In JulyAugust 2021, COVID-19 tests were 5357294, infection 747761, recovered was 669995, and died was 11250; respectively in Bangladesh. The mean of tests, infested, recovered, and statistics death was (35292.6452, and 38143.5806; 10856.2903, and 8101.0968; 8450.3871, and 11218.3871; 199.4194, and 177.7419). The ratio tests, infested, recovered, and death was varied from (4.9244 to 1.0498 and 4.6754 to $2.0197 ; 4.4823$ to 3.2699 and 6.3667 to $1.3367 ; 5.4725$ to 1.4418 and 4.7810 to $1.1795 ; 4.1734$ to 2.1352 and 4.7913 to 1.4519$)$ July, and August in 2021 of COVID-19. The positive correlation found between the date with the test, test with infested, recovered, and death of June 2021 by people where $\left(\mathrm{R}^{2}=0.0115,0.6245,0.0388\right.$ and 0.2917$)$ and in August, the positive correlation found between the test with infested, recovered, and death $\left(\mathrm{R}^{2}=0.7099,0.8988,0.7211\right.$ and 0.6454$)$ and the negative correlation found between tests with the date $\left(R^{2}=0.6454\right)$. All the Spearman correlation was positive with moderate to strong relationships between the variables at the 0.01 level in two-tailed. The mean Spearman correlation for tests was 0.656 (0.551-0.758), for infested was $0.669(0.433-0.818)$, for recovered was $0.564(0.433-0.709)$, for death was 0.737 (0.685-0.818). More people tested, infested, recovered, and died in July-August, 2021 than the earlier year. This experiment also showed a moderate to strong correlation among tests, infested, recovered, and death with COVID-19.

Keywords-SARS-CoV-2, COVID-19, tests, infested

\section{INTRODUCTION}

Severe Acute Respiratory Syndrome Coronavirus2 (SARS-CoV-2) is the instrumental etiology of 'Corona Virus Disease-2019' (COVID-19); formerly referred to as 'novel-Coronavirus-2019'. 
It was originated in Wuhan city, Hubei province, China, in early December 2019 [1, 2, 3]. The World Health Organization (WHO) avowed the designation of this novel coronavirus as 2019nCoV, and Public Health Emergency of International Concern' due to their rapid transmission and causing public and health-carerelated casualties worldwide, conjointly in the Asian nation, Bangladesh $[4,5]$. It is a movable pandemic that newly infected more than two hundred fifteen nations and regions in the world $[5,6]$.

It is the family of coronaviridae taxonomic cluster Sarbecovirus, genus Betacoronavirus, and order Noroviruses. These viruses have crown-like barbs on their outer surface $($ Corona $=$ Crown $)$, hence it was termed as Coronavirus [7]. It's a gram-positive mRNA disease collation early from twenty-six to thirty-two KB long, crownshape folks with the size of $80-160 \mathrm{nM}$, and nextgeneration sequencing, and biological procedure check of the ordering exposed COVID19 [8]. It was markedly matching (88\%) to 2 batderived SARS-like coronaviruses, and added distance from SARS-CoV (79.5\%), and MERS-CoV (50\%) [9].

In Bangladesh first cases of COVID-19 were detected on $8^{\text {th }}$ March 2020 [10], within the preliminary, investigative tests were shown by IEDCR solely, [11]. By the end of 2020, more than 80.3 million cases and 1.77 million associated deaths had 48 been reported worldwide
[12]. As of October 12, 2020, there were 379,738 confirmed cases including 5,555 deaths with the case fatality and recovery rate $1.85 \%$ and $77.5 \%$; respectively in Bangladesh [13]. In March 2021, the pandemic has rapidly swept across the globe infecting more than 122 million people, and more than 2.69 million people died $[14,15]$. The pandemic has rapidly swept across Bangladesh infecting more than 962 thousand people, recovering more than 475 thousand people, and more than 8 thousand people died $[16,17]$. On April 30, 2021, it was reached (5357294, 747761, 669995, and 11250) in Bangladesh [18, 19].

The shutdown was first declared on March 26, 2020, in Bangladesh [16]. the lockdown was declared on April fourteen, 2021 and the third lockdown was acknowledged on first July 2021 in Bangladesh. The lockdown effect on human life especially affects the poor family. The daily labor super more in those lockdown situations.

SARS-CoV-2 is no exclusion. However, some recent developing alternatives have accrued more changes in short times, causing concern around the world. Researchers expect that these mutant lines of the SARS-CoV-2 strain will not be the only concerning variants that emerge, as the sustained wild spread of SARS-CoV-2 in many parts of the world and selective gravities, such as vaccines, are creating ideal situations for further, virus fruition. The number of tests COVID-19 has been raised since the new stain was established in late April 2021, but it became riskier in July. 
Falls in the new Stein give a negative result but the affected person is living in the community, so it is going to be more difficult. To the governor of this state, the lockdown has been given for limiting to go outside. Considering the above fact, this experiment emphasizes the present condition of tests, infested, recovered, and death of people COVID-19 in Bangladesh numbers from JulyAugust 2021.

II.

METHODS

\section{Study design and Period}

,. We were collected publicly shared daily data from the website Directorate General of Health Services (DGHS) [20] and the Institute of Epidemiology Disease Control and Research [21, 22]. The collection of data periods was from July 1 to August 31, 2021 ( $\mathrm{N}=62$ days).

\section{Equations}

There is using some equations to identify the percentage of infected, recovered, and death observed in Bangladesh during the study period. The formula is given below

Tests $(\%)=\frac{\text { Tests }}{\text { Total Tests }} \times 100$

Infested $(\%)=\frac{\text { Infested }}{\text { Total Infested }} \times 100$

Recovered $(\%)=\frac{\text { Recovered }}{\text { Total Recovered }} \times 100$

Death $(\%)=\frac{\text { Death }}{\text { Total Death }} \times 100$

\section{Data Retrieval}

This experiment involved patients with tests, infested, recovered, and coronavirus death based on a positive result of the SARS-CoV-2 test by
DGHS, MoHFW, and IEDCR. Data from different medical parts in Bangladesh belong to 59 different organizations mixing the Bangladesh health sector. Those data were verified from different reporters, online news portals, and social networks [23, 24, 25].

\section{Statistical Data Analysis}

All the composed data were coded, rechecked, and entered into a catalog using Excel 2016. The regression connection was designed in July and August 2021. The link of the two variables was related using the Spearman rank correlation and statistical significance was accepted at $\mathrm{p}<0.01$, 0.05, and 0.1. All statistical analyses were performed using SPSS version 25.0 software.

III.

RESULTS AND

\section{DISCUSSION}

The present situation of coronavirus in Bangladesh from July to August 2021

On 8 March 2020, three individual cases were confirmed with COVID-19 in Bangladesh. Since then, tests, infestation, and death were regularly increased. From July to August 2021, the total infested, recovered, and death was presented in Fig 1. In July 2021, the total tests were 1094072 whereas, infested, recovered, and died were 336545,361962 , and 6282 respectively.

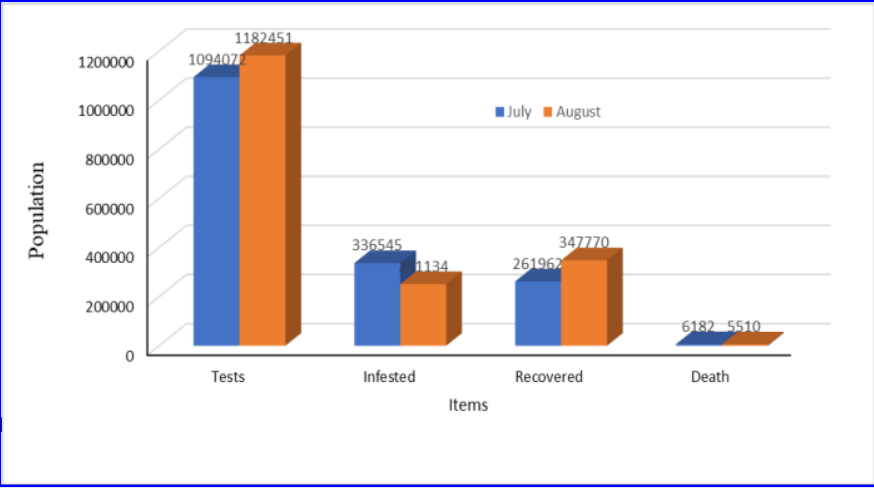


Fig. 1. In Bangladesh, the total number of COVID-19 tests, infested, recovered, and death, from July to August 2021

In August 2021, the total tests were 1182451 whereas infested, recovered, and died were 251134, 347770, and 5510 (Fig. 1). After the infestation of COVID-19 in December 2019, the infestation and death are increasing in the world and also in Bangladesh [17]. This study also found that the total tests, infested, recovered, and died were 5357294, 747761, 669995, and 11250 in Bangladesh from July to August 2021.

In case of tests: The mean of statistic and standard error of tests was (35292.6452, 1879.34804, and 38143.5806, 1519.59768) in July and August 2021. The maximum number of COVID-19 tests was 53877 (4.9244\%) on July, 28 and the minimum number of COVID-19 tests was $11486(1.0498 \%)$ on July 22 (Fig. 2). The maximum number of COVID-19 tests was 55284 (4.6754\%) on August, 28 and the minimum number of COVID-19 tests was 23882 (2.0197\%) on August, 22 (Fig. 3). Similar results were also observed in the second wave of COVID-19 in Bangladesh. The results of tests of COVID-19 were 1482, 69252, 244064, 460528, 409503, 362113, 397452, 389452, 436862, 454892, 424034, 392403, and 722848 in March to December 2020 to January to April 2021; respectively in Bangladesh [26].
In case of infested: The mean of statistic and standard error of infested was (10856.2903, 540.63497, and 8101.0968, 698.29871) in July and August 2021. The maximum number of COVID-19 was infested $16230(4.4823 \%)$ on July, 28 and the minimum number of COVID-19 was infested 3687 (3.2699\%) on July, 22 (Fig. 2). The maximum number of COVID-19 was infested 15989 (6.3667\%) on August, 2 and the minimum number of COVID-19 was infested 3357 (1.3367\%) on August, 22 (Fig. 3). Similar results were also observed in the second wave of COVID-19 in Bangladesh. The results of infestation of COVID-19 were 49, 7616, 39486, 98330, 92125, 73070, 50457, 44205, 57248, 58948, 21629, 11077, and 128555 in March to December 2020 to January to April 2021; respectively in Bangladesh [27].

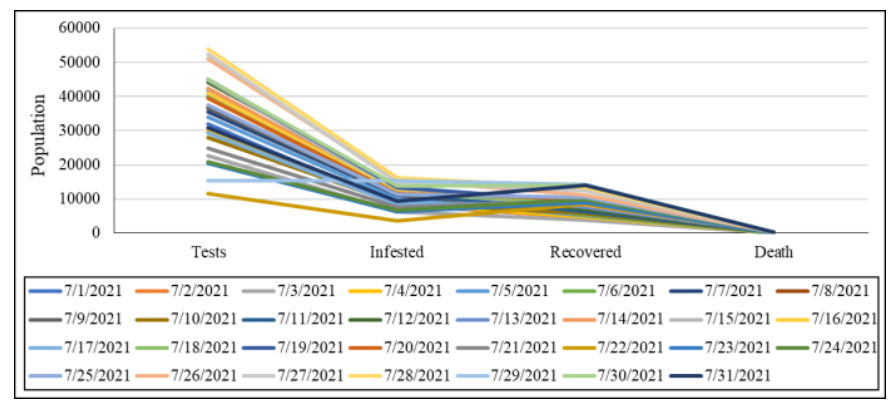

Fig. 2. Coronavirus update of the tests, infested, recovered, and death, during July 2021 in Bangladesh

In case of recovered: The mean of statistic and standard error of recovered was (8450.3871, 542.96642, and 11218.3871, 692.85777) in July and August 2021. The maximum number of COVID-19 was recovered 14336 (5.4725\%) on July, 29 and the minimum number of COVID-19 was recovered 3777 (1.4418\%) July, 3 (Fig. 2). 
The maximum number of COVID-19 was recovered 16627 (4.7810\%) on August, 8 and the minimum number of COVID-19 was recovered 4102 (1.1795\%) on August, 31 (Fig. 3). Similar results were also observed in the second wave of COVID-19 in Bangladesh. The results of recovered of COVID-19 was 25, 135, 7904, 34845, 76517, 69452, 71600, 48658, 56099, 70367, 22285, 17140, and 150816 in March to December 2020 to January to April 2021; respectively in Bangladesh $[11,28]$.

In case of death: The mean of statistic and standard error of death was (199.4194, 5.96707, and 177.7419, 11.17899) in July and August 2021. The maximum number of COVID-19 was death $258(4.1734 \%)$ on July, 27 and the minimum number of COVID-19 was death 132 (2.1352\%) July, 2 (Fig. 2). The maximum number of COVID-19 was death $264(4.7913 \%)$ on August, 5 and 10 and the minimum number of COVID-19 was death 80 (1.4519\%) August, 28 (Fig. 3). Similar results were also observed in the second wave of COVID-19 in Bangladesh. The results of the death of COVID-19 were 6, 163,

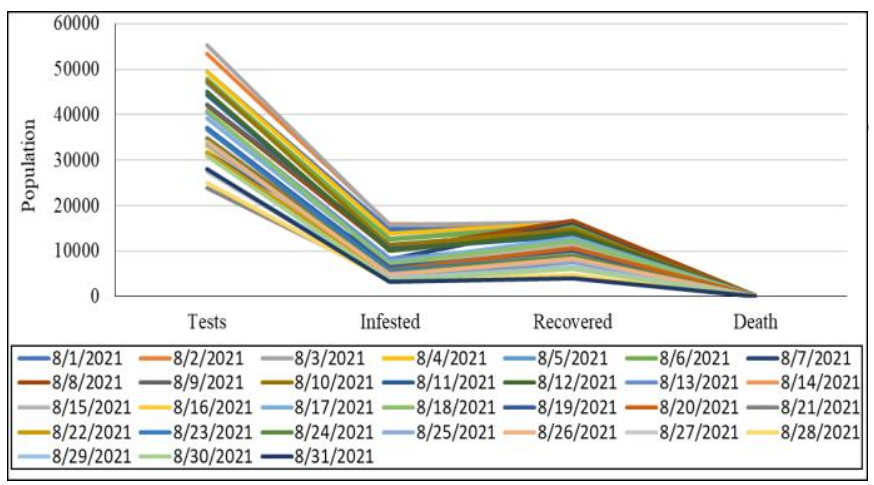

Fig. 3. Coronavirus update of the tests, infested, recovered, and death, during August 2021 in Bangladesh
Spearman's Rho correlation: Spearman's rankorder correlation was used to reconnoiter the connection between variables (tests, infested, recovered, death) in coronavirus of Bangladesh. There were statistically significant relations stated between variables. The outcomes revealed a positive, moderate to a strong connection between the variables at the 0.01 level in two-tailed and the total number was $\mathrm{N}=62$ (Table 1 ).

In case of tests: The results revealed a moderate relationship between tests with infested $\left(r_{\mathrm{s}}=0.758\right)$, recovered $\left(r_{\mathrm{s}}=0.551\right)$, and death $\left(r_{\mathrm{s}}=0.685\right)$ people of COVID-19. In case of infested: the results revealed a moderate to a strong relationship between infested with tests $\left(r_{\mathrm{s}}=0.758\right), \quad$ recovered $\left(r_{\mathrm{s}}=0.433\right)$, and death $\left(r_{\mathrm{s}}=0.818\right)$ people of COVID-19. In case of recovered: The results revealed a moderate to a strong relationship between recovered with tests $\left(r_{\mathrm{s}}=0.551\right)$, infested $\left(r_{\mathrm{s}}=0.433\right)$, and death $\left(r_{\mathrm{s}}=0.709\right)$ people of COVID-19. In case of death: The results revealed a moderate to a strong relationship between death with tests $\left(r_{\mathrm{s}}=0.685\right)$, infested $\left(r_{\mathrm{s}}=0.818\right)$, and recovered $\left(r_{\mathrm{s}}=0.709\right)$ people of COVID-19. Before calculating $r_{\mathrm{s}}$, visual inspection of the scatterplot of tests, infested, recovered and death confirmed that the relationship between these variables was nonlinear and monotonic. Similar results were also observed in a study where it is in stark contrast to the downward trajectory in Europe, China, and elsewhere in Asia, where the number of new cases 
has seen a decline ahead of an anticipated second wave [24, 29] and in Bangladesh, the mean Spearman correlation for incidence was 0.20 (range 0.66 to 0.76 ) and for mortality was 0.35 (range 0.75 to 0.85 ). Another also found similar results and the mean results of Spearman correlation for tests, infested, recovered, and death was $0.31,0.35,0.796,0.808$ in Bangladesh on April $2021[25,30]$.

TABLE 1. SPEARMAN'S RHO CORRELATION ANALYSIS AMONG THE TESTS, INFESTED, RECOVERED, AND DEATH OF COVID-19 IN BANGLADESH

\begin{tabular}{|c|c|c|c|c|}
\hline Correlations & Tests & Infested & Recovered & Death \\
\hline $\begin{array}{l}\text { Correlation } \\
\text { Coefficient }\end{array}$ & 1.000 & $0.758^{* *}$ & $0.551^{\text {** }}$ & $0.685^{* *}$ \\
\hline Significance & - & 0.000 & 0.000 & 0.000 \\
\hline $\mathrm{N}$ & \multicolumn{4}{|c|}{62} \\
\hline $\begin{array}{l}\text { Correlation } \\
\text { Coefficient }\end{array}$ & $0.758^{* * *}$ & 1.000 & $0.433^{\text {** }}$ & $0.818^{* *}$ \\
\hline Significance & 0.000 & - & 0.000 & 0.000 \\
\hline $\mathrm{N}$ & \multicolumn{4}{|c|}{62} \\
\hline $\begin{array}{l}\text { Correlation } \\
\text { Coefficient } \\
\end{array}$ & $0.551^{* * *}$ & $0.433^{* *}$ & 1.000 & $0.709^{* *}$ \\
\hline Significance & 0.000 & 0.000 & - & 0.000 \\
\hline $\mathrm{N}$ & \multicolumn{4}{|l|}{62} \\
\hline $\begin{array}{l}\text { Correlation } \\
\text { Coefficient }\end{array}$ & $0.685^{* *}$ & $0.818^{\text {** }}$ & $0.709^{* *}$ & 1.000 \\
\hline Significance & 0.000 & 0.000 & 0.000 & - \\
\hline $\mathrm{N}$ & \multicolumn{4}{|c|}{62} \\
\hline
\end{tabular}

**Correlation is significant at the 0.01 level (2tailed), $\mathrm{N}=62$ days

\section{Correlation between tests of COVID-19 people with infested, recovered, and dead people during May and June 2021}

Correlation schoolwork was completed to

establish the connection between the plague of people with recovered and death of people by COVID-19 in Fig. 4.

In June, a positive correlation was observed between the date with the test, test with infested, recovered, and dead people of COVID-19 in
Bangladesh. It was evident that the positive and negative equations were $\mathrm{y}=123.27 \mathrm{x}-5 \mathrm{E}+06$, $0.2273 x+2832.9, \quad 0.0569 x+6440.6 \quad$ and $y=0.0017 x+138.9$ gave a good fit to the data and the coefficient of determination $\mathrm{R}^{2}=0.0115$, $0.6245,0.0388$ and 0.2917 fitted regression line had a significant regression coefficient without tests with dates.

TABLE 2. THE RELATIONSHIPS BETWEEN THE INFESTATION OF PEOPLE OF COVID19 WITH INFESTED, RECOVERED, AND DEATH OF PEOPLE DURING THE STUDY PERIOD

\begin{tabular}{|c|c|c|c|c|c|}
\hline Month & $\begin{array}{c}\text { Regression } \\
\text { items }\end{array}$ & $\begin{array}{l}\text { Regression } \\
\text { equation }\end{array}$ & $\mathbf{A}$ & B & C \\
\hline \multirow{4}{*}{ June } & D vs T & $y=123.27 x-5 E+06$ & 1.15 & 0.0566 & 0.0115 \\
\hline & T vs I & $y=0.2273 x+2832.9$ & 62.45 & 0.0112 & 0.6245 \\
\hline & T vs $R$ & $y=0.0569 x+6440.6$ & 3.88 & 0.0287 & 0.0388 \\
\hline & T vs D & $y=0.0017 x+138.9$ & 29.17 & 0.0017 & 0.2917 \\
\hline \multirow{4}{*}{ August } & D vs T & $y=-784.03 x+3 E+07$ & 70.99 & NS & 0.7099 \\
\hline & T vs I & $y=0.4357 x-8516.7$ & 89.88 & 0.0521 & 0.8988 \\
\hline & T vs $R$ & $y=0.3872 x-3549.7$ & 72.11 & 0.0015 & 0.7211 \\
\hline & T vs D & $y=109.21 x+18733$ & 64.54 & NS & 0.6454 \\
\hline
\end{tabular}

$\mathrm{A}=\%$ Role of individual factor; $\mathrm{B}=$ Significance; $\mathrm{C}=\mathrm{R}^{2}$ value; $\mathrm{D}$ vs $\mathrm{T}=$ Date vs Tests; $\mathrm{T}$ vs $\mathrm{I}=$ Tests vs Infested; $\mathrm{T}$ vs $\mathrm{R}=$ Tests vs Recovered; and $\mathrm{T}$ vs $\mathrm{D}=$ Tests vs Death.

In August, a positive correlation was observed between the test with infested, recovered, and death people and a negative relationship found between dates with daily tests of COVID-19 in Bangladesh. It was evident that the positive and negative equations were $\mathrm{y}=0.4357 \mathrm{x}-8516.7$, $0.3872 \mathrm{x}-3549.7, \quad 109.21 \mathrm{x}+18733$ and $\mathrm{y}=-$ $784.03 \mathrm{x}+3 \mathrm{E}+07$ gave a good fit to the data and the coefficient of determination $R^{2}=0.7099$, $0.8988,0.7211$ and 0.6454 fitted regression line had a significant regression coefficient without This is an open access article distributed under the Creative Commons Attribution License 
tests with the dates (Table 2 and Fig. 4). The findings were the positive correlation found between infestation with recovered and death by people $\left(\mathrm{R}^{2}=0.4804\right.$ and $0.3159 ; 0.7242$ and $0.4902 ; 0.4432$ and $0.3449, \mathrm{p}<0.05)$ in 2020 [ 28 , 31]. In Myanmar, the first wave was reported on 16 July 2020 where the cases and death were 374 , and 6; respectively, and the last local transmission was found. The second wave started on 16 August in Rakhine State where the total Cases, recoveries, and death was 32,351, 14,706, and 765; respectively during $2020[32,33]$.

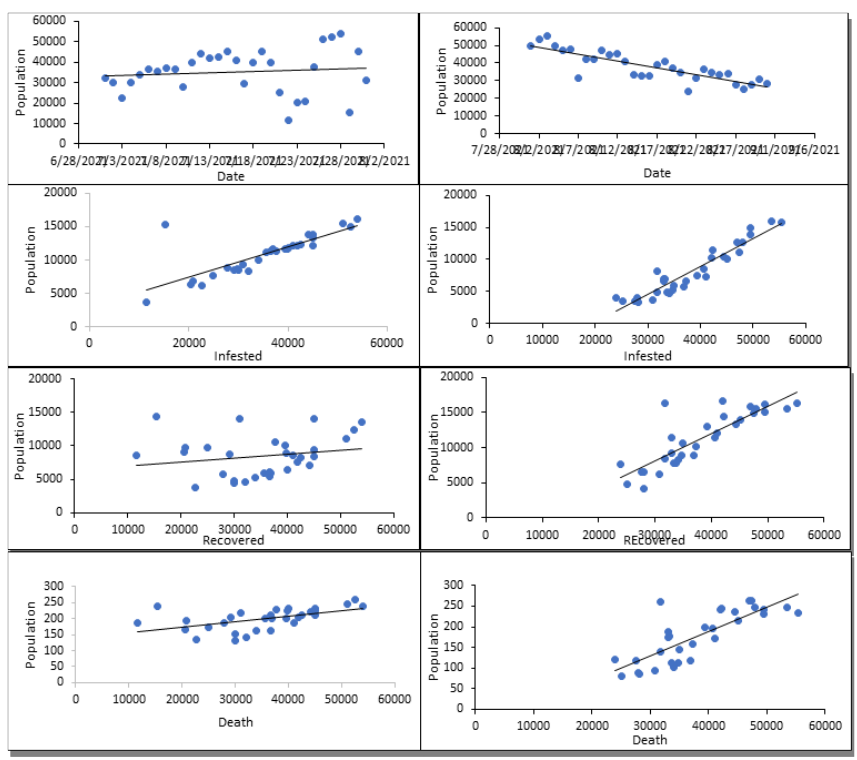

Fig. 4. Relationship between dates with tests (First pair), tests with infested (Second pair), recovered (Third pair) and death (Forth pair) people of Bangladesh

IV. CONCLUSION

COVID-19 has spread over sixty-four regions of Bangladesh. The continuing outburst of COVID19 contagions has stressed the status of the rapid and precise 118 workroom diagnoses to limit the feast and suitably treat those patients who have a severe contagion. More people infested and died in April, 2021 than previous year. This study also indicated that there is moderate to strong relation among tests, infested, recovered and death with COVID-(2020-2021). In this condition, people should sidestep community places. It would not be right to go out without a vital necessity. If you have to go, you will have to use the masks and return home as soon as likely after dying at work. The government should develop with new mega plans to help the deprived so that COVID-19 can be kept under control.

Author Contributions: This work was conducted in collaboration with all authors. Author $\mathrm{AUK}^{1}$ was planned, structured, wrote, revised, and rechecked the manuscript thoroughly. $\mathrm{AUK}^{5}$ was analyzed the research data and revised the manuscript. RA, FUK, SK, ASF, ST, and BD were contributed to revise and improve the manuscript thoroughly. All authors reviewed carefully and approved the final version of the manuscript.

Conflict of interest: Authors declare that there is no conflict of interest.

Funding agency: The study was not funded by any authority.

\section{References}

1. B. Ganesh, T. Rajakumar, M. Malathi, N. Manikandan, J. Nagaraj, A. Santhakumar, A. Elangovan, Y.S. Malik. (2021). "Epidemiology and pathobiology of SARS-CoV-2 (COVID-19) in comparison with SARS, MERS: An updated overview of current knowledge and future perspectives". Clinical Epidemiology and Global 
Health.

10:

100694.

https://doi.org/10.1016/j.cegh.2020.100694

2. A. U. Khan, A. A. Proma, M. Akter, M. M.

Rahaman, and S. Das. "A Review on Coronavirus

Disease (COVID-19 ) Epidemic Threat for Global

Health in 2020". American Journal of Microbiological Research, 2020, Vol. 8, pp. 5762, 2020.

3. D. Sonal, D. N. Pandit, and M. A. Haque. (2021). "An IoT Based Model to Defend COVID19 Outbreak". International Journal of Innovative Technology and Exploring Engineering. 10(7): 152-157.

4. J. Yang, Y. Zheng, X. Gou, K. Pu, Z. Chen, Q. Guo, et al. (2020). "Prevalence of comorbidities and its effects in patients infected with SARSCoV-2: a systematic review and metaanalysis". International Journal of Infectious Diseases. 94: 91-95.

5. A. U. Khan, F. U. Khan, S. Khanom, A. U. Khan, and A. S. Afsana, A.S. (2020). "COVID-19 Pandemic Situation in Bangladesh". International Conference on Multidisciplinary Industry and Academic Research (ICMIAR). Candelaria, Quezon, Philippines, in December 12, 2020. 1:25, 2020. Available at www.iiari.org

6. S. Farooq, and Z. Ngaini. (2020). "Natural and Synthetic Drugs as Potential Treatment for Coronavirus Disease 2019 (COVID-2019). Chemistry Africa. 1(4): 1-13.

7. F. A. Rabi, M. S. Al Zoubi, G.A. Kasasbeh, D.M. Salameh, A.D. Al-Nasser. (2020). "SARSCoV-2 and coronavirus disease 2019: what we know so far". Pathogens. 9: E231.

8. P. C. Woo, Y. Huang, S. K. S. Lau, and K. Y. Yuen. (2010). "Coronavirus genomics and bioinformatics analysis". Viruses. 2: 1804-1820. Available from: Doi: 10.3390/v2081803.

9. H. Lu, C. W. Stratton, and Y. W. Tang. (2020). "Outbreak of Pneumonia of Unknown Etiology in Wuhan China: The Mystery and the Miracle". Journal of Medical Virology. 92: 401-402. Doi:10.1002/jmv.25678.

10. N. Sakib, A. Bhuiyan, S. Hossain, F. Al Mamun, I. Hosen, A. H. Abdullah, et al. (2020). "Psychometric Validation of the Bangla Fear of COVID-19 Scale : Confirmatory Factor Analysis and Rasch Analysis Psychometric Validation of the Bangla Fear of COVID-19 Scale: Confirmatory factor analysis and Rasch analysis". International journal of mental health and addiction. 1-12. https://doi.org/10.1007/s11469$\underline{020-00289-\mathrm{x}}$

11. A. U. Khan, A. U. Khan, and A. S. Afsana. (2021). "Information about the COVID-19 in Bangladesh". International Conference on Social Sciences Business Management and Education. August 15, 2021, The Philippines. 2(1): 13.

12. I. Hossain, M. H. Khan, M. S. Rahman, A. R. Mullick, and M. M. Aktaruzzaman. (2020). "The Epidemiological Characteristics of an Outbreak of 2019 Novel Coronavirus Diseases (COVID-19) In Bangladesh: A Descriptive Study". Journal of Medical Science and Clinical Research. 8: 544551.

Doi:

https://dx.doi.org/10.18535/jmscr/v8i4.94

13. ECDPC. European Centre for Disease Prevention and Control, (2021). "COVID-19 
situation updates worldwide". URL https://www.ecdc.europa.eu/en/geographicaldistribution-2019-ncov-cases (Accessed $1^{\text {st }}$ May 2021).

14. A. U. Khan, M. S. A, Talucder, M. Das, S. Noreen, and Y. S. Pane. (2021). Prospect of The Black Pepper (Piper nigrum L.) as Natural Product Used to an Herbal Medicine. Macedonian Journal of Medical Sciences. 9(F):1-11. https:// doi.org/10.3889/oamjms.2021.7113

15. JHUSM. (2020). "The Johns Hopkins University School of Medicine. Coronavirus Resource Center USA: The Johns Hopkins University". https://coronavirus.jhu.edu/map.html. (Accessed 20 ${ }^{\text {th }}$ March 2021)

16. WHO. (2020). "World Health Organization, Bangladesh".

https://www.who.int/docs/defaultsource/searo/ban gladesh/covid-19-whobangladesh-situationreports/who-covid-19-update-33-

20201012.pdf?sfvrsn=8e5f58c7_ 2. Accessed October 14, 2020

17. A. U. Khan, A. U. Khan, and A. S. Afsana. (2021). Information about the COVID-19 in Bangladesh. International Conference on Social Sciences Business Management and Education in the Philippines. 15 August 2021. 2(1): 13.

18. A. U. Khan, R. Akter, F. U. Khan, S. Khanom, A. U. Khan, A.S. Afsana. (2021). "Second wave and pandemic situation of COVID-(2020-2021) in Bangladesh". Research Square. 1-12. Doi: https://doi.org/10.21203/rs.3.rs-668459/v1.

19. A. A. Shawon, and S. Mamun. (2020). "Bangladesh likely to extend shutdown till May 16”. Dhaka Tribune, May 02, 2020.

20. M. A. Mannan. (2020). "Coronavirus: Jashore farmers take the hit for falling vegetable prices". UNB/Special, April 04, 2020. Available from: https://unb.com.bd/category/Special/coronavirusjashore-farmers-take-the-hit-for-falling-vegetableprices/48681

21. A. H. Mansur. (2020). "Taming coronavirus rampage: Ensuring food security during pandemic". The Daily Star/Business, April 20, 2020. Available from: https://www.thedailystar.net/business/news/ensuri ng-food-security-during-pandemic-1894711

22. A. U. Khan, and A. U. Khan. (2020). "The Impact of COVID-19 Pandemic Threat on Agriculture Sector". Proceeding of 8th International Conference of Biotechnology, Environment and Engineering Sciences in 18 October 2020, Stockholm-Sweden. P. 15. Doi: $\underline{10.46617 / i \mathrm{cbe} 8}$.

23. A. U. Khan, I. J. Ema, A. S. Afsana, A. U. Khan, A. Zannaty, M. R. Faruk, and S. Rahman. (2021). "Effects of Coronavirus Disease (COVID19) on Agricultural Sectors in Bangladesh: A Review". International Journal for Asian Contemporary Research. 1(1): 89-97. Available online from: https://www.ijacr.net/upload/i jacr/2021-12-1012.pdf

24. MHFWD. (2020). "Ministry of Health and Family Welfare and Directorate of Health Studies. Bangladesh Health Observatory". 
25. IEDCR. (2020). Institute of Epidemiology

Disease Control and Research. "Coronavirus

Disease 2019 (COVID-19) Information

Bangladesh".

26. DGHS. (2020). (Dashboard of Directorate

General of Health Services). "The Government Republic of Bangladesh". $8^{\text {th }}$ April to June 2020. https://www.dghs.gov.bd/index.php/bd/

27. CCD. (Coronavirus COVID-19 Dashboard). (2020). $\quad$ http://103.247.238.81/webportal/pag es/covid19.php

28. A. U. Khan, R. Akter, F. U. Khan, S. Khanom, A. U. Khan, A.S. Afsana. (2021). "Second wave and pandemic situation of COVID-(2020-2021) in Bangladesh”. Qubahan Academic Journal. 1(4): 25-31. Doi: https://doi.org/10.48161/qaj.v1n4a74 29. J. W. Lai, and K. H. Cheong. "Superposition of COVID-19 waves, anticipating a sustained wave, and lessons for the future". Wiley. July: 112. Doi: 10.1002/bies.202000178.

30. T. Szmuda, S. Ali, T. V. Hetzger, P. osvall, P. Sloniewski. (2020). "Are online searches for the novel coronavirus (COVID-19) related to media or epidemiology? A cross-sectional study". International Journal of Infection Disease. 97: 386-390.

https://doi.org/10.1016/j.ijid.2020.06.028

31. A. U. Khan, F. U. Khan, S. Khanom, and A.

U. Khan. (2020). "Novel Coronavirus Disease (COVID-19): Pandemic Situation in Bangladesh". Nujs Journal of Regulatory Studies. 5(2):1-10.

32. COVID-19 Surveillance News. (2020).

"Naypyidaw: Ministry of Health and Sports". https://www.mohs.gov.mm/ (15 October 2020, date last accessed)

33. F. D. Salman and J. H. Kamel. (2021). COVID-19 Dental Students Knowledge of Medical Technical Institute Dental Assistant Department (Erbil-Iraq) A Comparative Study. Acta Scientific Medical Sciences. 5(11): 86-100. 